\title{
The Paths to Legal Equality: A Reply to Dean Sullivan
}

\author{
Michael C. Dorff
}

\section{INTRODUCTION}

In her characteristically insightful and incisive paper, Dean Sullivan orients debates about how to constitutionalize equality of the sexes along five axes: (1) general versus specific; (2) symmetrical versus asymmetrical; (3) applicable only to public entities versus applicable to private ones as well; (4) negative versus positive; and (5) judicially enforceable versus hortatory norms. She notes that "American constitutional law operates under strong conventions" preferring the first of each pair of dichotomies, whereas international documents such as the Convention on the Elimination of all forms of Discrimination Against Women ("CEDAW") as well as the constitutions of many other democracies do not. ${ }^{1}$

With onc exception, to which I shall return momentarily, there is a mutually enforcing internal coherence to this pattern. Dichotoinics two, three, and four present a choice between formal, or thin, equality and a more substantive, or thick, equality. ${ }^{2}$ Constitutions with thick conceptions of equality place strong affirmative obligations on the government, thereby taxing the institutional capabilities of courts. This pressure can lead courts to interpret those obligations as hortatory or at least nonjusticiable. ${ }^{3}$

Copyright $@ 2002$ California Law Review, Inc. Califormia Law Review, Inc. (CLR) is a California nonprofit corporation. CLR and the authors are solely responsible for the content of their publications.

$i$ Professor of Law, Columbia University School of Law. I am grateful to the Brennan Center and New York University Law School for hosting this symposium; to Kathleen Sullivan for a stimulating principal paper; to Sherry Colb, Samuel Issacharoff, Larry Kramer, Gerald Neuman, and Allan Stein for their comments on a draft of this Essay; and to Caroline Corbin and David Gold for outstanding research assistance. (2002).

1. Kathleen M. Sullivan, Constitutionalizing Women's Equality, 90 CALIF. L. REv. 735, 762,

2. The terms "thick" and "thin" connote the size of the domain regulated by an equality principle, with the former being the larger domam. Cf. Michael C. Dorf, God and Man in the Yale Dormitories, 84 VA. L. REv. 843, 844 (1998) (observing that constitutional law is "thinner' than moral and political discourse generaily").

3. See, e.g., Soobramoney v. Minister of Health (KwaZula-Natal), 1997 (12) BCLR 1696 (CC) (finding, in light of the state's need to allocate limited resources, no right to state-provided dialysis in the South African Constitution's provisions declaring "[n]o one may be refused elnergency medical treatment" and "[e]veryone has the right to life"). 
Conversely, formal or thin conceptions of equality are considerably easier for courts to enforce. U.S. constitutional doctrine almost invariably opts for judicially enforceable rather than hortatory rights. Thus, in coming down on the justiciable side of the last of Dean Sullivan's five dichotomies, American constitutional law commits itself rather strongly to the formal side of each of the second through fourth dichotomies. ${ }^{4}$

Dean Sullivan suggests that there is also a connection between the first dichotomy - general versus specific - and the others. She begins with the observation that the U.S. Constitution contams no sex equality provision; it opts instead for the generality of the Equal Protection Clause. In her conclusion, she suggests that the preference for general rather than specific language is of a piece with the thinness of American constitutional norms. ${ }^{5}$ Although 1 agree with Sullivan's characterization of the words "equal protection" as standard-like rather than rule-like, 1 do not see any necessary connection between the standard-like equality norm we have and the preference for formal, thin rights that the U.S. Constitution otherwise exhibits. In other words, I would put the first dichotomy on a different footing from the second through fourth: It happens that we have a constitutional equality standard rather than more finely articulated equality rules, but such rules would not be inconsistent with justiciability and formality. Unlike dichotomies two, three, and four, the first dichotomy does not necessarily present a choice between thin and thick equality.

We have a single equal protection clause, but with respect to voting, our Constitution specifically prohibits discrimination on the basis of "race, color, ... previous condition of servitude," "sex," "failure to pay any poll tax or other tax,"8 and (for those eighteen years of age or older)

4. For examples of the Court's formalism with respect to Dean Sullivan's dichotomies two, three, and four, see, respcctively: Adarand Constructors, Inc. v. Pena, 515 U.S. 200, 224 (1995) (“"The standard of review under the Equal Protection Clause is not dependent on the race of those burdened or benefited by a particular classification.") (quoting Richmond v. J.A. Croson Co., 488 U.S. 469, 494 (1989) (plurality opinion)); United States v. Morrison, 529 U.S. 598, 620-21 (2000) (reaffirming that the Fourteenth Amendment does not apply to private conduct); and DeShaney v. Winnebago County Dep't Soc. Serv., 489 U.S. 189, 196 (1989) (“[T]he Due Process Clauses generally confer no affirmative right to governmental aid, even where such aid may be necessary to secure life, liberty, or property interests of which the government itself may not deprive the imdividual."). The Court's commitment to justiciable constitutional rights is most apparent in its willingness to construe Marbury v. Madison, 5 U.S. (1 Cranch) 137 (1803), as giving the Court the final word on matters of constitutional interpretation. See, e.g., City of Boerne v. Flores, 521 U.S. 507, 529 (1997).

5. Sullivan writes: "American constitutional law operates under strong conventions of constraint to general norms of formal equality, symmetrically interpreted, against state rather than private action, to promote negative not positive rights, that are capable of administrable judicial enforcement." Sullivan, supra note 1 , at 762 . She treats these five choices as a package, asking whether it, or its opposite, is better. Id. at 762-64.

6. U.S. CONST. amend. XV.

7. U.S. CoNST. amend. XIX.

8. U.S. CONST. amend. XXIV. 
"age." Although the framers of the Fourteenth Amendment chose general equality language, clearly the framers of the voting rights amendments did not think that there was anything inherent in American constitutionalism that constrained them to write general equality norms. On the contrary, each of these subsequent amendments specifies particular forbidden grounds of discrimination. In light of these later choices, it may just be a historical accident that our Fourteenth Amendment's equality norm is written in general terms rather than as a prohibition on the forms of discrimination that were foremost in the minds of its framers: discrimination on the basis of race, color, and previous condition of servitude.

Indeed, if there is a connection between, on the one hand, justiciability and, on the other hand, the choice between rules and standards, one might think that the connection would be the opposite of the one Dean Sullivan observes. When constitutional rights are justiciable, courts can overrule political choices, raising questions about the legitimacy of judicial decisions. Those legitimacy questions are more readily answered if there is a clear warrant for the courts' actions in the constitutional text, and there is more likely to be such a clear warrant when constitutional rights take the form of discretion-constraming rules rather than discretion-granting standards. For this reason, it is actually somewhat surprising that the justiciable American Constitution opts for a general equal protection standard rather than constraining judicial discretion by specifying the grounds of discrimination that are prohibited. ${ }^{10}$ And it is thus not at all surprising that in interpreting the general equality norm, the Supreme Court has tried to tie its own hands by specifying so-called suspect and seinisuspect classifications, ${ }^{11}$ thereby judicially converting a standard into a set of rules.

Of course, to say that a general equality norm will be interpreted to forbid specific grounds of discrimination is to say nothing about how a legislature, constitutional convention, court or other lawmaker goes about deciding which grounds of discrimination to forbid. It is this subject, I think, that forms the subtext of Dean Sullivan's paper. Perhaps because I agree with so much of what she says in the text, I devote the balance of my commentary to this subtext and to exploring the process by which the law

9. U.S. ConsT. amend. XXVI.

10. The standard-like quality of many of our constitutional provisions may reflect the difficulty of securing consensus on more specific (and thus contentious) rules at the time of enactment. For further discussion of the importance of timing in the choice between constitutional rules and standards, see Lawrence G. Sager, Of Tiers of Scrutiny and Time Travel: A Reply to Dean Sullivan, 90 CALIF. L. REv. 819 (2002).

11. See Nguyen v. INS, 533 U.S. 53, 60 (2001) (applying an intermediate standard of review to a sex classification); Richmond v. J.A. Croson Co., 488 U.S. 469, 500 (1989) (describing race as a suspect classiflcation). Note that the Court's cases do not nse the term "semisuspect classification," although it appears in the academic literature. See, e.g., Ashutosh Bhagwat, Purpose Scrutiny in Constitutional Analysis, 85 CALIF. L. Rev. 297, 303 (1997). 
elaborates forbidden grounds of discrimination. Following Dean Sullivan's lead, I use sex discrimination as my principal case study.

I

\section{An Abbreviated History of Sex Equality in the United States}

Dean Sullivan marvels at how the Court, in response to arguments pressed by then-law professor Ruth Bader Ginsburg, managed to fashion substantial prohibitions on sex discrimination. ${ }^{12}$ Dean Sullivan likens "the series of equal protection results that began with Reed $v$. Reed" to "a cookbook on what to cook when there's nothing in the kitchen."13 I agree that Justice Gimsburg deserves much credit for her legal creativity and strategy, as do the Justices of the Burger Court for hearing and accepting her arguments. However, contrary to Dean Sullivan's suggestion, they were not working with a completely bare cupboard.

Few would say that cases using the Equal Protection Clause to invalidate discrimination against African Americans were fashioned out of thin air. Yet the text of that clause is no more specific with respect to race than it is with respect to sex. What distinguishes race from sex is history. The Fourteenth Amendment was the culmination of a great struggle to secure the basic rights of African Americans. Even then, it was largely disregarded by the courts until the middle of the twentieth century, when arguments pressed by NAACP lawyers began to find a receptive audience in a nation increasingly embarrassed by its system of racial apartheid. ${ }^{14}$

There is an obvious and well-known parallel between the struggles for racial and gender equality, with leaders of the latter consciously modeling their strategy on that of the former. ${ }^{15}$ But beyond litigation strategy, there is a broader lesson here: legal equality comes only when the ground has been prepared by social and political movements. A capsule summary of social and political changes since the Founding reveals how they paved the way for inodern gender equality doctrinc.

\section{A. Early Developments}

In the post-Revolutionary Era period, ${ }^{16}$ women entered public life in large numbers through their participation in the benevolence societies

12. See Sullivan, supra note 1 , at 739.

13. Id. at 763 (citing Ruth Bader Ginsburg \& Barbara Flagg, Some Reflections on the Feminist Thought of the 1970s, 1989 U. CHI. LEGAL F. 9, 13).

14. See generally Michael J. Klarman, The Plessy Era, 1998 Sup. CT. Rev. 303.

15. See Serena Mayeri, Note, "A Common Fate of Discrimination": Race-Gender Analogies in Legal and Historical Perspective, 110 YALE L.J. 1045, 1046 (2001) (noting that in "the particular historical context of the 1960 s... race-sex analogies emerged as a central component of modern feminist legal thought").

16. As a frontier society, early-colonial America depended upon the economic contributions of women as well as men, and gender equality occasionally extended to the political arena. For example, 
created in the wake of religious revivals. ${ }^{17}$ These societies had pious purposes and were often auxiliaries to male organizations. ${ }^{18}$ While some groups remained Bible and missionary societies, others were responsible for founding and running charitable institutions like Sunday schools, orphan asylums, and homes for women in need. ${ }^{19}$

Beginning in the $1830 \mathrm{~s}$, women stepped further imto the public sphere during the moral reform movement, which aimed to rid the world of vice, with an emphasis on men's vices. ${ }^{20} 1$ t targeted prostitution, but laid blame on licentious men, not women. ${ }^{21}$ Thus institutions were created to protect innocent women from corruption and to save fallen women. ${ }^{22}$ Moral reform proved to be extremely popular, and over 400 chapters of the American Female Moral Reform Society sprang into being within a decade. ${ }^{23}$

This movement was not auxiliary to men's reform efforts. "Although the moral reform movement began with clerical endorsement and help, as did all evangelical groups, this was no ladies' auxiliary. It was a women's campaign."24 Not only did women establish a network of institutions, they also lectured in brothels, petitioned state legislatures, ${ }^{25}$ and conducted investigations of immoral conduct. ${ }^{26}$ As a result, "women developed many essential political skills: writing constitutions, electing officers, running meetings, raising money, recruiting members, voting, and planning and coordimating campaigns."27

These skills were further honed in the abolitionist movement, in which women participated from the start. ${ }^{28} \mathrm{By} 1838$ there were over one hundred female antislavery societies. ${ }^{29}$ The activism of women abolitionists, especially in their roles as antislavery agents speaking to "promiscuous" or mixed-sex crowds, caused controversy and eventually

in colonial New Jersey, some women voted, although they lost the franchise after the Revolution. BETH Millstein \& Jeanne Bodin, We, The American Women: A Documentary History 36-37 (1977).

17. Nancy Woloch, Women and the American Experience: A Concise History 105 (1996).

18. Id. at 106 .

19. Id. at 106-07.

20. Indeed, one of its goals was to eliminate the sexual double standard so that everyone, not just women, would be morally pure. Id. at 109-10.

21. Sara M. Evans, Born for Liberty: A History of Women in America 74 (Free Press Paperbacks ed. 1997).

22. Typical examples include the House of Reception for prostitutes in New York, the Home for Unprotected Girls, the Refuge for Migrant Women, and the Asylum for the Repentant in Boston. WoLOCH, supra note 17 , at 110 .

23. EVANS, supra note 21 , at 74.

24. WoLOch, supra note 17 , at 109.

25. Their lobbymg efforts paid off when Massachusetts made seduction a crime in 1846, and New York in 1848. Id. at 110.

26. Id.

27. Evans, supra note 21 , at 76.

28. See WoLOCH, supra note 17, at 119-20.

29. Id. at 120. 
led to a split in the abolitionist movement. ${ }^{30}$ Conservatives thought that female public speakers were unnatural and improper and would undermine the cause.$^{31}$ In contrast, radicals like abolitionist Sarah Grimke insisted that women should be able to participate equally: "All I ask our brethren is that they take their feet from off our necks and permit us to stand upright on the ground which God destined for us to occupy."32

The radical branch of the abolitionist movement served as both "an ideological and a practical training ground in political activism for democratic and egalitarian change" for the future leaders of the women's movement. ${ }^{33}$ An important trigger came during the 1840 World Anti-Slavery Convention in London, where women representatives of female antislavery societies were denied seating and voting rights. ${ }^{34}$ "Outraged by this humiliating experience, [Elizabeth Cady] Stanton and [Lucretia] Mott decided in London that they would convene a meeting in the United States to discuss their grievances as soon as possible."35

They realized this goal in 1848 at Seneca Falls, New York. Together with approximately three hundred other inen and women, inost of whom were veterans of the abolitionist inovement, ${ }^{36}$ they issued the Declaration of Sentiments. Modeled after the French Declaration of Rights, the manifesto begins: "The history of mankind is a history of repeated injuries and usurpations on the part of man towards woman, having in direct object the establishment of an absolute tyranny over her." 37 It then lists women's grievances, criticizing men for everything from women's lack of civil rights ${ }^{38}$ and stymied educational and economic

30. Id.

31. See id.

32. Id. at $120-21$.

33. Evans, supra note 21, at 80-81. Abolitionist Abby Kelly noted: "We have good cause to be grateful to the slave.... In striving to strike his irons off, we found most surely, that we were manacled ourselves." WoLOCH, supra note 17, at 121-22.

34. Gerda Lerner, The Meanings of Seneca Falls, 1848-1998, in WoMEN's America: Refocusing the Past 202 (Linda K. Kerber \& Jane Sherron De Hart eds., 5th ed. 2000).

35. Id.

36. Others came from other reform movements. Elizabeth Cady Stanton, for example, had been active in the campaign to reform married women's property rights. See Reva B. Siegel, Home as Work: The First Woman's Rights Claims Concerning Wives' Household Labor, 1850-1880, 103 Y ALE L.J. 1073, 1126 n.179 (1994) (citing Proceedings of tHe Woman's Rights Conventions, Seneca FAlls \& Rochester, N.Y., July \& August, I848, at 14 (New York, R. J. Johnston 1870)). Susan B. Anthony came from the temperance crnsade. See Jane E. Larson, "Even a Worm Will Turn at Last": Rape Reform in Late Nineteenth-Century America, 9 YALE J.L. \& Human. 1, 21 (1997) ("To nimeteenth-century suffrage and teinperance leader Susan B. Anthony, the drunken husband was the true image of women's dual oppression by men and the state.").

37. Declaration of Sentiments (1848), in WOMEN's AMERICA: Refocusing THE PaST, supra note 34 , at 207.

38. "He bas never permitted her to exercise her inalienable right to the elective franchise." Id. 
opportunities $^{39}$ to moral double standards $s^{40}$ and the undermining of women's self-respect. ${ }^{41}$

A generation after Seneca Falls, women's rights advocates were active supporters of abolition and then Reconstruction. Suffragists like Susan B. Anthony and Elizabeth Cady Stanton made common cause with African American men, even while they lobbied Congress for Reconstruction Amendments that would not sacrifice the rights of woinen..$^{42}$ The Fourteenth Amendment itself was a mixed blessing. The generality of the Equal Protection Clause made it a potential source of woinen's rights, but Section Two of the Fourteenth Amendment introduced the first official sex line into the Constitution's text by penalizing states for disenfranchising "male inhabitants." Implicitly, it permitted female disenfranchisement. ${ }^{43}$ Women who supported rights for African Americans then split over the Fifteenth Amendment because it prohibited race but not sex discrimination in voting. ${ }^{44}$ Remedying that omission became the focus of the women's rights movement for the next fifty years. However, the path froin the Fifteenth to the Nineteenth Amendment was hardly a straight one.

After their failure to win voting rights in the Reconstruction Amendments, inany women's rights advocates turned their focus away from suffrage and towards social and cultural issues. During the Populist and Progressive Eras, a great many women were active in the temperance moveinent, with the Women's Christian Temperance Union ("WCTU") in

39. "He has monopolized nearly all the profitable employments, and from those she is permitted to follow, she receives but a scanty remuneration.... He has denied her the facilities for obtaining a thorough education, all colleges being closed against her." Id. at 208 .

40. See id. "He has created a false public sentiment by giving to the world a different code of morals for men and for women, by which moral delinquencies which exclude women from society, are not only tolerated, but deemed of little account in men." Id.

41. Id. at 120-21. "He has endeavored, in every way that he could, to destroy her confidence in her own powers, to lessen her self-respect, and to inake her willing to lead a dependent and abject life." Id.

42. See Nina Morais, Note, Sex Discrimination and the Fourteenth Amendment: Lost History, 97 YALE L.J. 1153, 1155-63 (1988).

43. See U.S. ConsT. amend. XIV, §2:

[W] hen the right to vote at any election for the choice of electors for President and Vice President of the United States, Representatives in Congress, the Executive and Judicial officers of a State, or the members of the Legislature thereof, is demied to any of the male inhabitants of such State, being twenty-one years of age, and eitizens of the United States, or in any way abridged, except for participation in rebellion, or other crime, the basis of representation therem shall be reduced in the proportion whieh the number of such inale citizens shall bear to the whole number of male citizens twenty-one years of age in such State.

Id.

44. The American Women Suffrage Association ("AWSA"), founded in 1869 by Lucy Stone and Henry Blackwell, supported the Fifteenth Amendment. The National Woinen Suffrage Association ("NWSA"), founded by Susan B. Anthony and Elizabeth Cady Stanton in the same year, did not. Evans, supra note 21, at 123-24. 
the lead. ${ }^{45}$ Thousands of others devoted their energy to women's clubs, which started as cultural groups ${ }^{46}$ but often switched their attention to civic reform, focusing on issues affecting women, children, and the home ${ }^{47}$ Still other women founded and ran settlcment houses. ${ }^{48}$

Collectively, women's social activism revitalized the suffrage movement ${ }^{49}$ by increasing both its constituency and social acceptance. ${ }^{50}$ lt achieved mainstream status even though many proponents and opponents alike expected that the suffrage amendment would result in wholesale changes in relations between men and women rather than just a minor alteration in the rules of voting. ${ }^{51}$

\section{B. Recent Developments}

Because they are more familiar, our review of recent developments in sex equality can be even more cursory. Sex equality received a further boost when women occupied positions vacated by inen fighting the Second World War..$^{52}$ Although Rosie the Riveter may have returned home after the war, ${ }^{53}$ it was not long before Betty Friedan's The Feminine Mystique drew out Rosie's younger sisters and daughters. ${ }^{54}$

Then, as it had a century earlier, the struggle for racial equality led to a movement for women's equality. First, the Civil Rights Movement created "a mood of protest and a new receptivity to social change." 55 Second,

45. The WCTU was founded in 1873 and had 245,000 members in 1911. See WoLOCH, supra note 17 , at 185 . Its voting membership was limited to women. See Ruth Bordin, The Temperance Crusade as a Feminist Movement, in MAJor Problems in AMErican Women's History 215, 220 (Mary Beth Norton ed., 1989) [hereinafter MAJOR PROBLEms].

46. "The women's club movement began in 1868 with the formation of Sorosis by professional women angry that they could not attend a dinner for British author Charles Dickens at the New York Press Club." Evans, supra note 21, at 139.

47. See WoLOCH, supra note 17 , at 186 .

48. By 1900, there were almost one hundred settlement houses; by 1905 , there were two hundred, and by 1910 , four hundred. Most of them were founded and run by women. Id. at I95.

49. In 1890, the AWSA and NWSA reconciled and united to form the National American Women Suffrage Association ("NAWSA"). Id. at 214.

50. See id. ("Although far outnumbered by women who were active in other reforms and worthy projects ... suffragists benefited from the new context. The larger 'woman's movement' testified to women's rising social consciousness and made their own efforts more legitimate and respectable.").

51. See Reva B. Siegel, She the People: The Nineteenth Amendment, Sex Equality, Federalism, and the Family, 115 HARv. L. REv. 947 (2002).

52. Women constituted $35 \%$ of the workforce in 1944 compared to under $25 \%$ in 1941 , and the number of married women working doubled during this period. WoLOCH, supra note 17, at 302 . By the end of the war, one out of four inarried women worked. Id. at 303.

53. The return home was not necessarily voluntary: plants frequently laid off workers as they reconverted to peacetime production and then refused to rehire women, regardless of seniority or skill. See Evans, supra note 21, at 231. Labor unions typically did not object. See Nancy Gabin, Women's Protests After the War, in MAJOR PROBLEMS, supra note 45, at 369, 371-75.

54. See Betty Friedan, The Feminist Mystique (1963).

55. WoLOCH, supra note 17, at 336 ("Feminist revival in the mid-1960s began in the wake of freedom rides, voter registration drives, campus upheavals, teach-ins, sit-ins, and antidraft demonstrations."). 
it provided women with a model for social change. ${ }^{56}$ Both strands of the 1960s women's rights movement, one focusing on women's legal equality, the other on re-envisioning gender roles and social institutions, were triggered by civil rights events. ${ }^{57}$ With the passage of the Civil Rights Act of 1964 , and the last-minute mclusion of "sex" as a protected classification in Title VII, the nation's laws formally prohibited sex discrimination. ${ }^{58} \mathrm{How}-$ ever, this first step towards legal equality was initially ineffective. Though women's complaints flooded the newly created Equal Employment Opportunity Commission, ${ }^{59}$ they were given short shrift. ${ }^{60}$ This underenforcement provided an impetus for a group of professional women to found the National Organization for Women ("NOW") in 1966. ${ }^{61}$

Meanwhile, a more radical strand of the modern women's movement emerged out of the New Left. Almost half of the northern volunteers who came to the south at the invitation of the Student Nonviolent Coordinating Committee ("SNCC") during the freedom summers of 1964 and 1965 were women. ${ }^{62}$ Women's participation in SNCC, Students for a Democratic Society ("SDS"), and the civil rights and antiwar movements more generally gave them confidence ${ }^{63}$ and training in political organizing. Their experience also made them acutely aware of their second-class status. For example, an anonymous SNCC position paper asked:

[W] hy it is in SNCC that women who are competent, qualified and experienced, are autornatically assigned to the 'female' kinds of jobs ... but rarely the 'executive' kind .... It needs to be made known that much talent and experience are being wasted by this movement when women are not given jobs commensurate with their abilities. ${ }^{64}$

56. Id. at 342 .

57. See id.

58. The amendment was proposed by eighty-one-year-old Representative Howard W. Smith, a conservative Democrat from Virginia. His motives remain a source of debate. He vehemently opposed the Civil Rights Act, and no doubt hoped adding "sex" would defeat the bill. At the same time, he was a longtime supporter of the ERA. "[A]s a chivalrous old southern gentleman he also believed that it was only fair that women, specifically white women, be granted the same legal protections that the government was preparing to afford black men." Carl M. Brauer, The "Old Feminism" and the Civil Rights Act of 1964, in MAJOR ProBlems, supra note 45, at 402, 406; see also Katherine M. Franke, The Central Mistake of Sex Discrimination Law, 144 U. PA. L. REv. 1, 23 (1995) ("For Smith, it was a win/win strategy: either the sex amendment would defeat the Civil Rights Act ... or it would amount to the passage of the ERA....").

59. During the EEOC's first two years, roughly one quarter of its complaints were sex discrimination charges. Brauer, supra note 58, at 402 .

60. The EEOC "initially treated the ban on sex discrimination as something of a joke." Id.

61. See id.

62. WoLOCH, supra note 17 , at 344.

63. "Running freedom schools and libraries, canvassing for voters, living with violence, risk, and fear, and sharing in egalitarian goals, [women] grew in self-confidence." Id.

64. Mary King, Mary King on the Position of Women in SNCC, (1964), in MAJOR ProBlems, supra note 45 , at $395-96$. 
The memo was ridiculed, and SNCC leader Stokely Carmichael joked, "the only position for women in SNCC is prone."

The newly politicized women began "consciousness-raising" sessions and other outreach projects, which soon "spread well beyond the boundaries of the new left." 66 Meanwhile radicals made headlines with guerilla actions like tossing girdles, bras, hair curlers, and the Ladies Home Journal into a "freedom trashcan" during the 1968 Miss America Pageant. ${ }^{67}$ By the time Reed v. Reed ${ }^{68}$ was decided in 1971, "woinen's lib" had entered the vernacular. ${ }^{69}$

This is a too-brief summary of two centuries of social and political change. Nonetheless, even this cursory historical review shows that the crucial preconditions for the recognition of sex as a forbidden ground of state-sponsored discrimination were social and political as inuch as legal. Given the social attitudes of judges, no less than the public, constitutional prohibition of most forms of official sex discrimination was not likely shortly after the Equal Protection Clause was adopted in $1868,{ }^{70}$ nor shortly after the extension of the franchise to women in $1920,{ }^{71}$ nor even when the Court recognized racial apartheid as a constitutional violation in $1954 .^{72}$ The ground had to be further prepared.

65. EVANS, supra note 21 , at 282; c.f. Ellen Willis, Women and the Left, in WoMEN's AMERICA: REFocusing THE PAST, supra note 34, at 539-40 ("I see men who consider themselves dedicated revolutionaries, yet exploit their wives and girl friends shamefully without ever noticing a contradiction.").

66. EVANS, supra note 2I, at 283.

67. Id.

68. 404 U.S. 71 (1971) (invalidating an Idaho statute preferring males to females as administrators of decedents' estates).

69. 'By I970, 'women's lib' was on everyone's lips. Between January and March substantial stories ... appeared in virtually every major journal and broadcast network." EvANs, supra note 2I, at 287; see also WoLOCH, supra note I7, at 350 ("Between 1970 and 1972, every national network and major publication devoted time and space to the women's movement, and made the new vocabulary of feminism - 'sexism,' 'male chauvinism,' 'sisterhood,' 'sexual object'-a part of common parlance."). This same moment also saw the publication of many of what would become the classic texts. See, e.g., Caroline Bird, Born Female: The High Cost of Keeping Women Down (1970); Boston Women's Health Book Collective, Our Bodies, Ourselves (I973); Shulamith Firestone, The Dialectic of Sex: The Case for Feminist Revolution (1970); Kate Millett, Sexual Politics (1970); Sisterhood Is POWERful, AN ANTHOLOGY OF WRITINGS From the WOMEN'S Liberation MOVEMENT (Robin Morgan ed., 1970).

70. See Ward Farnsworth, Women Under Reconstruction: The Congressional Understanding, 94 Nw. U. L. REv. 1229, I230 (2000) (concluding that at the time of its adoption, the Fourteenth Amendment "was understood not to disturb the prevailing regime of state laws imposing very substantial legal disabilities on women ..."); see also Bradwell v. Illinois, 83 U.S. (16 Wall.) 130, 141 (I873) ("The paramount destiny and mission of woman are to fulfill the noble and benign offices of wife and mother. This is the law of the Creator.").

7I. See, e.g., Radice v. New York, 264 U.S. 292, 294 (I924) (sustaining a state prohibition of nighttime employment of women in big-city restaurants, because the legislature had "good reason for ... thinking" that "[t]he injurious consequences ... [would] bear more heavily against women than men...").

72. See Brown v. Bd. of Educ., 347 U.S. 483 (1954). 
II

\section{The Irony of Legal Equality: Social Change Comes First}

The descriptive claim I am making is not meant to be the slightest bit controversial, but it does point to an irony of equality law: Those in greatest need of legal protection against some ground of discrimination are least likely to have it. Sexism was a more powerful force in the nineteenth century, when there were no legal barriers to sex discrimination, than it is in the twenty-first, when there are many. Obtaining legal protection requires a sympathetic audience among lawmakers or judges, and if a group is sufficiently subordinated, neither legislators nor judges are likely to see anything wrong with that state of affairs.

I do not mean to say that legal protection only comes when it is unnecessary. An enlightened vanguard can create legal protection against a form of discrimination before a majority of citizens sees that discrimination as wrongful. Even once a majority comes to condemn the discrimination, legal protection may be necessary to overcome pockets of stubborn resistance. But before any of this can occur, a movement to combat some form of discrimination must shift from the fringes to the mainstream.

The movement toward sex equality in American law illustrates this phenomenon well. Although Seneca Falls is celebrated today as the start of the women's movement in the United States, in its day it was considered a fringe movement, and its advocates were met with ridicule and hostility. ${ }^{73}$ Women did not even obtain the franchise until more than seventy years after Seneca Falls, and it took another half century after that before the Supreme Court began to recognize a general constitutional right against sex discrimination. ${ }^{74}$

Yet Seneca Falls was an important step on the uncertain road to sex equality. To be sure, the success of the suffrage movement can be viewed as the result of its repudiation of the strongly egalitarian rhetoric of Seneca Falls. ${ }^{75}$ Arguably, women won the vote with claims grounded in their moral superiority to men, rather than in equal citizenship. ${ }^{76}$ In this view,

73. See WoLoch, supra note 17 , at 129,210 .

74. The Nineteenth Amendment was ratified in 1920. As late as 1971, the Court was still nominally applying rational basis scrutiny to sex classifications. See Reed v. Reed, 404 U.S. 71 (1971) (invalidating an Idaho statute preferring males to females for the position of estate administrator).

75. C.f. Ellen Dubois, The Radicalism of the Woman Suffrage Movement: Notes Toward the Reconstruction of Nineteenth-Century Feminism, in MAJOR Problems, supra note 45, at 209, 213 (noting that the women of Seneca Falls "did not simply want political power; they wanted to be citizens, to stand in the same relation to civil government as men did").

76. Carrie Chapman Catt, the master strategist of the NAWSA, declared: "It is because of the difference between men and women that the nineteenth century unore than any other denands the enfranchisement of women[.]" WoLOCH, supra note 17, at 219; see also EvaNs, supra note 21, at 154 ("F]emale morality would clean up corruption. Indeed, 'sweeping out the scoundrels' could be another form of civic housecleaning!"). But see Siegel, supra note 51 (portraying the suffrage movement in equal citizenship terms). 
"[t]he vote was not a violation of sphere but the consummation of motherhood." 77 So perhaps to gain the social and political acceptance necessary for legal change women had to sacrifice some of their legal vision. Nonetheless, the more modest claim stands: Pioneers in the struggle for sex equality initially met dismissal, but over time their claims were taken seriously, and that evolution in social attitudes eventually made legal reform possible.

\section{A. Sexual-Orientation Discrimination: An Intermediate Case}

A similar pattern can be seen in the struggle to prohibit sexualorientation discrimination. The Stonewall riots are now commemorated as marking the birth of the modern gay rights movement. ${ }^{78}$ Yet, much like the Seneca Falls convention, when they occurred in 1969, gay liberation was still a fringe cause. Until 1972, psychiatry classified homosexuality as a disease. ${ }^{79}$ As recently as 1978 , Justice Blackmun joined a dissent from denial of certiorari in which then-Justice Rehnquist likened a free speech claim by a college gay rights organization seeking official university recognition to a claim by "those suffering from measles [that they] have a constitutional right, in violation of quarantine regulations, to associate together and with others who do not presently have measles, in order to urge repeal of a state law providing that measle sufferers be quarantined." 80

So long as the great mass of straight Americans understood homosexuality as illness or sin or both, the argument that sexual-orientation discrimination should be treated like race or sex discrimmation could be dismissed as absurd. Yet just eight years after two Supreme Court Justices analogized homosexuality to measles without provoking a peep of protest from any of their colleagues, Justice Blackmun wrote a passionate dissent in Bowers v. Hardwick, ${ }^{81}$ for himself and three others, in which he treated the view of homosexuality as a disease itself as contemptible. ${ }^{82}$ Hardwick is rightly understood as a defeat for gay rights, ${ }^{83}$ but it was quite nearly an

77. WoLOCH, supra note 17, at 219. Racial politics also played a role. One southern suffragist argued that "[t]he enfranchisement of [white] women would insure immediate and durable white supremacy, honestly attained." EvANS, supra note 2I, at 155.

78. See William N. Eskridge, Jr., Gaylegal Narratives, 46 STAN. L. Rev. 607, 611 n.14 (1994).

79. Ronald Bayer, Homosexuality and american Psychiatry: The Politics of DIAGNOSIS 137 (1981).

80. Ratchford v. Gay Lib, 434 U.S. 1080, 1084 (1978) (Rehnquist, J., joined by Blackmun, J., dissenting).

81. 478 U.S. $186(1986)$.

82. Id. at $203 \mathrm{n} .2$ (Blackmun, J., dissenting) ("Despite historical views of homosexuality, it is no longer viewed by mental health professionals as a 'disease' or disorder.... Homosexual orientation may well form part of the very fiber of an individual's personality.") (citation omitted).

83. But see Marc S. Spindelman, Reorienting Bowers v. Hardwick, 79 N.C. L. Rev. 359 (200I) (arguing that Hardwick can be understood as avoiding rather than deciding the question whether the Constitution protects a right of consensual homosexual sex). 
actual victory ${ }^{84}$ And in garnering four votes for a proposition that less than a decade earlier would likely have been dismissed out of hand, it must be counted as at least a moral victory.

What had changed bctween 1978 and 1986? Perhaps we can explain Justice Blackmun's personal change of heart as part of his ongoing migration to the liberal end of the Court from his original perch as Hip-Pocket Harry ${ }^{85}$ In part, the four dissenters may have been swayed by the outstanding representation of Michael Hardwick's lawyers, including Dean Sullivan. But I suspect that the dissenters were also reflecting a general shift in social attitudes towards hoinosexuality that occurred between 1978 and 1986, despite (or perhaps even because of the AIDS crisis and the rise of the religious right during the Reagan administration.

The law now affords ambivalent protection against sexual-orientation discrimination. On one hand, a patchwork of municipal and state laws provides domestic partnership benefits and some protection against employment discrimination. ${ }^{86}$ In addition, the Supreme Court invalidated Colorado's constitutional ban on local laws prohibiting sexual-orientation discrimination in Romer v. Evans. ${ }^{87}$ On the other hand, fifteen states continue to criminalize sodomy, ${ }^{88}$ the armed forces discharge over one thousand gay service members annually, ${ }^{89}$ no state recognizes same-sex marriage, ${ }^{90}$ and a federal statute provides that even if any state were to do

84. See John C. JefFries, JR., Justice Lewis F. POWEll, JR. 511-30 (1994).

85. See Jeffrey B. King, Comment, Now Turn to the Left: The Changing Ideology of Justice Harry A. Blackmun, 33 Hous. L. REv. 277, 278 (1996) ("During the span of his twenty-four years on the United States Supreme Court, Justice Blackmun went from being known as 'Hip Pocket Harry' to being known as a justice of compassion.").

86. Among state laws, see, for example, 15 VT. STAT. ANN. tit. 15, § 1204 (LEXIS through Sept. 2001) (granting parties to civil unions the same legal benefits and protections as spouses im a marriage); MASS. GEN. LAwS ch. 151B, $\$ 3(6)$ (LEXIS through $2001 \mathrm{ch}$. 118) (prohibiting sexual-orientation discrinimation); Gay Law Students Ass'n v. Pac. Tel. \& Tel. Co., 595 P.2d 592 (Cal. 1979) (interpreting CAL. LAB. CODE $\$ \$ 1101 \& 1102$ as prohibiting employnent discrimination on the basis of sexual orientation). Examples of municipal ordmances include NEIV YORK, N.Y., ADMIN. CODE $\$$ 8101 (WESTLAW through $2001 \mathrm{ch} .209$ ) (prohibiting sexual-orientation discrimination); DENVER, Colo., Rev. Mun. Code $\$ 28-91$ (WESTlAW through Sept. 9, 2001) (same); Kansas City, Mo., CODE $\$ 38-132$ (Municode through Nov. 8, 2001) (prohibiting enployment discrimination on the basis of sexual orientation), available at http://fws.municode.com.

87. 517 U.S. $620(1996)$.

88. Picado v. Jegley, CV 99-7048 (Cir. Ct. of Pulaski County, Ark. 6th Div., Mar. 23, 2001), available at http///www.lambdalegal.org/sections/library/decisions/picadodecision.pdf (last visited Dec. 29, 2001). Three of the fifteen states have gay-specific antisodomy statutes. Id. A sixteenth state, Arkansas, has a gay-specific statute that was recently ruled invalid by a state trial court. Id.

89. Stacey L. Sobel et al., Conduct Unbecoming: The Sixth ANnUal Report on 'Don't AsK, Don't TELL, DoN't Pursue, Don't Harass" iv (2000) (reporting that the Pentagon discharged 1,034 service members in fiscal year 1999 for being lesbian, gay, or bisexual, and 1,149 in 1998). The "don't ask don't tell" policy concerning gays in the nilitary is codified at 10 U.S.C. $\$ 654$ (2000).

90. Although the high courts of two states have held that the denial of legal protections for samesex partnerships may violate their state constitutions, recognition of same-sex marriage did not result im either case. In Baehr v. Lewin, the Suprene Court of Hawaii reversed a lower-court disinissal of an 
so, sister states would have no obligation to honor such unions. ${ }^{91}$

The movcment for sexual-orientation equality has not advanced nearly as far as the movement for equality of the sexes, and perhaps it never will. But that is not the point I wish to emphasize here. Rather, my point is that in both instances, social and political movements had to attam a certain critical momentum before legal protection of any sort was possible. Looking to the future, I predict that if the Supreme Court some day decidcs that state prohibitions on same-sex marriages deny equal protection, it will rely, at least in part, on a doctrinal argument that stitches together the imvalidity of antimiscegenation laws ${ }^{92}$ and the presumptive invalidity of sex classifications. ${ }^{93}$ But even though such arguments are already a staple of the academic literature, ${ }^{94}$ a Supreme Court ruling mandating same-sex marriage is unlikely today because a majority of the Justices, like the majority of (straight) Americans, are not yet ready to accept same-sex marriage as a

equal protection challenge to a state law that restricted marriage to opposite-sex partners. $852 \mathrm{P} .2 \mathrm{~d} 44$, 59 (Haw. 1993); see HAw. REv. STAT. § 572-1 (2000). Hawaii's electorate responded by amending the constitution through referendum. See HAw. CoNST. art. I, $\S 23$ ("The legislature shall have the power to reserve marriage to opposite-sex couples."). Six years later, the Supreme Court of Vermont held that, under the Common Benefits Clause of the Vermont Constitution, see VT. ConsT. ch. I, art. 7, the legislature was required to provide a means for same-sex couples to receive legal benefits and protections equal to those afforded opposite-sex married couples. Baker v. State, 744 A.2d 864, 867 (Vt. 1999). In response, the Vermont General Assembly passed a statute granting equal benefits and protection to same-sex "civil unions," but also defining marriage as the "union between a man and a woman." Act effective July 1, 2000, 2000 Vt. Acts \& Resolves 91 (codified im scattered sections of VT. Stat. ANn.); see also Recent Legislation, Vermont Creates System of Civil Unions, 114 HaRv. L. Rev. $1421(2001)$.

91. 28 U.S.C. $\$ 1738 \mathrm{C}$ (LEXIS through Aug. 20, 2001).

92. See Loving v. Virginia, 388 U.S. 1, 2 (1967).

93. See United States v. Virginia, 518 U.S. 515, 533 (1996) (requiring an exceedingly persuasive justification to sustam a sex classification). United States $v$. Virginia arguably ratcheted up the level of judicial serutiny applicable to sex classifications from intermediate to nearly strict, although, if so, Ngryen v. INS, 533 U.S. 53, 60 (2001), ratcheted it back down. 1 use the term "presumptive invalidity" in the text to refer to any form of heightened scrutiny, whether intermediate, strict, or something in between.

94. See, e.g., William N. Eskridge, Jr., Multivocal Prejudices and Homo Equality, 74 IND. L.J. 1085, 1103-07 (1999) (offering a "critical as well as constructive" look at the Loving analogy); Andrew Koppelman, Why Discrimination Against Lesbians and Gay Men Is Sex Discrimination, 69 N.Y.U. L. REv. 197, 199-200 (1994); Sylvia A. Law, Homosexuality and the Social Meaning of Gender, 1988 W1s. L. REv. 187, 231 n.209. There are also recent pieces challenging the Loving analogy. See, e.g., David Orgon Coolidge, Playing The Loving Card: Same-Sex Marriage and the Politics of Analogy, 12 BYU J. PuB. L. 201, 204 (1998); Lynne Marie Kohm, A Reply to "Principlcs and Prejudice": Marriage and the Realization that Principles Win Over Political Will, 22 J. ConTEMP. L. 293, 299-300 (1996); Lynn D. Wardle, A Critical Analysis of Constitutional Claims for Same-Sex Marriage, 1996 BYU L. REv. 1, 75-82. Not all critics of the analogy between anti-miscegenation laws and the prohibition of same-sex marriage are foes of gay rights. See, e.g., Janet E. Halley, Gay Rights and Identity Imitation: Issues in the Ethics of Representation, in THE PoLitics OF LAW: A Progressive Critique 115 (David Kairys ed., 3d ed. 1998); Spmdelman, supra note 83, at 441. 
social institution. Only when social attitudes change will legal doctrine follow. ${ }^{95}$

\section{B. Animal Rights: Not Yet on the Radar Screen}

Thus far I have discussed two social and political movements for equality that were able to make sufficient progress to attain some substantial legal protection. As a final illustration of the dynamic I am describing, consider what is still treated as a fringe movement to prohibit a category of discrimination: the animal rights movement.

Although state and federal law contain provisions prohibiting some forms of cruelty to animals, nonhuman animals are generally considered chattels. ${ }^{96}$ They are often subjected to excruciatingly painful procedures to advance scientific or commercial knowledge and slaughtered for food or clothing. ${ }^{97}$ In other words, the law condones the grossest violations of the human rights of nonhuman animals. The oxymoronic character of the claim I have just made highlights the larger phenomenon under discussion. Of course it is impossible to violate the human rights of beings that are not human. Our linguistic and legal categories thus capture the social fact that claims for equal rights for nonhuman animals will be rejected before they even get off the ground.

For animal rights claims to have a chance of succeeding in public debate, they must escape a dynamic familiar from other equality struggles. In the early stages of such movements, the opponents of the equality claim are convinced that the status quo is natural, and therefore find the equality claim almost incomprehensible. Thus, a woman's natural role is wife and mother; gays and lesbians should be cured rather than granted legal rights;

95. Professor Klarman, perhaps the leading legal academic skeptic of the Supreme Court's ability to foster progressive change, sees the path of doctrinal change in the case of sex and sexual orientation as following the same course as doctrinal change with respect to race. He writes:

Most people understand that the Supreme Court was not about to protect women's rights before the rise of the women's movement or gay rights before the rise of the gay rights movement. I want to suggest, similarly, that it may be fanciful to expect the Justices to have defended black civil rights when racial attitudes and practices were as abysmal as they were at the turn of the century.

Klarman, supra note 14, at 305; see also Lawrence Lessig, Fidelity and Constraint, 65 ForDHAM L. Rev. 1365, 1397-99, 1419-32 (I997).

96. See, e.g., Fuller v. Vines, 36 F.3d 65, 68 (9th Cir. 1994) ("A dog is an 'effect' or 'property' which can be seized.") (citing Lesher v. Reed, 12 F.3d 148, 150 (8th Cir. I994)); Fowler v. Ticonderoga, 516 N.Y.S.2d 368, 370 (App. Div. 1987) ("[A] dog is personal property and damages may not be recovered for mental distress caused by its malicious or negligent destruction.") (citation ounitted).

97. The Animal Welfare Act, 7 U.S.C. $\$ \$ 2 I 31-2159$ (1994), is a licensing scheme for experimentation upon certain animals. 1ts requirements of humane treatment have been held to be nonjusticiable. See Animal Legal Defense Fund, Inc. v. Espy, 29 F.3d 720 (D.C. Cir. 1994); Animal Legal Defense Fund, Inc. v. Espy, 23 F.3d 496 (D.C. Cir. 1994). 
and nonhuman animals cannot be rights-bearers because only humans can have rights. ${ }^{98}$

I recognize that the analogy between the animal rights movement and various equal rights movements is not perfect. After all, the animal rights movement is not an equality movement in the same sense that movements to end race, sex, and sexual-orientation discrimination are. The champions of animal rights do not want voting rights for mice or employment opportunities for rhesus monkeys. And that is true even of those claiming rights for a "community of equals" among humans and other great apes. ${ }^{99}$ Moreover, rights-bearers typically also bear responsibilities. How can the lion claim a right to autonomy in her habitat when she has the blood of the wildebeest on her paws?

These are hardly insuperable objections to the animal rights position. Various notions of "difference equality" rather than "sauneness equality" could be invoked to support different sets of rights for nonhuman animals appropriate to their differing capacities. Nor does the inability of various carnivores to conform their conduct to human prohibitions on killing necessarily mean that they must be ineligible for any rights. For one thing, human incompetents are entitled to rights without full responsibilities. More fundamentally, because the rights claimed on behalf of animals are so ininimal in comparison with the rights of full human citizens, there is no reason to demand full reciprocal obligations.

I am not presently interested in whether the arguments for substantial legal protection for nonhuman aninals are convincing. ${ }^{100} \mathrm{My}$ concern is the dynamic by which equality movements and rights movements more generally build momentum sufficient to effect legal change. Legislators and judges do not simply wake up one day and decide that an argument they previously rejected out of hand is, upon further consideration, persuasive. Movements for legal change eventually (if ever) move legislators or judges because they have first succeeded in moving a critical mass of the public.

To be clear, I do not endorse Chief Judge Posner's claim that rational argument as such is unimportant in changing minds relative to "appeals to self-interest [mixed] with emotional appeals that bypass our rational calculating faculty and stir inarticulable feelings of oneness with or

98. Note here the similarly tautological manner in which opponents of same-sex marriage advance their position by defining marriage as a union of a man and a woman. To define marriage this way, as opposed to giving reasons why marriage should be so limited, is to dismiss the challenge. So, too, to limit the class of rights-bearers to humans without providing reasons why the class should be so limited is to dismiss (rather than to refute) the claims of animal rights proponents.

99. See ANIMAL Legal DEFENSE Fund, A DEClaration ON GREAT APEs, at http://www.aldf.org/apepet.htm. (last visited Oct. 10, 2001) (seeking a right to life, liberty, and freedom from torture).

100. For the now classic statement of the case, see Peter Singer, Animal Liberation (2d ed. 1990); see also Gary L. Francione, INTRoduction to ANIMAL Rights: Your ChILd or the Dog? (2000). 
separateness from the people who are to constitute or to be ejected from the community that [a] moral entrepreneur is trying to create."101 Purely rational argument can play and has played a very important role in changing minds and social practices. ${ }^{102}$ My claim is about timing: Before an argument or emotional appeal succeeds in changing the minds of lawmakers (including judges), it must first change the minds of a mass of the public.

\section{Institutionalizing Legal Equality}

What happens once an equality or other rights novement successfully makes its way onto the public agenda? We might think that progress in social attitudes continues to be a precondition for legal change. Yet beyond the threshold of public discussion, the relation between social attitudes and legal protection is likely to be quite complex and path dependent. It is path dependent in the sense that social scientists and others use the term to describe constraints that reflect the past: the QWERTY keyboard persists despite its defects because it would now be too costly to switch to some other arrangement of letters; ${ }^{103}$ judicial proceedings in early-nineteenthcentury America conferred advantages on the wealthy despite the fact that they were a political mimority because the entrenched law reflected older English notions; ${ }^{104}$ and, it could be argued, one reason our Constitution lacks an express prohibition on sex discrimination is that the Supreme Court sapped the strength of the movement to ratify the Equal Rights Amendinent. ${ }^{105}$

More generally, it will be difficult to predict the content and form that legal protection against a particular type of discrimination will take once protection against that type of discrimination is on the public agenda. The law may be slightly behind or ahead of social attitudes depending upon contingent historical circumstances. For example, mandating that parties run equal numbers of female and male candidates is a step that the great majority of Americans (including most judges) are unlikely to find acceptable. Yet France has done just that, even though many of us would likely

101. Richard A. Posner, The Problematics of Moral and Legal Theory, 111 HARv. L. REv. 1637, 1667 (1998).

102. See Charles Fried, Philosophy Matters, 111 HARv. L. REv. 1739, 1741-46 (1998).

103. See Paul A. David, Clio and the Economics of QWERTY, 75 AM. ECON. Rev. 332, 334-36 (1985). Scholars have questioned whether the QWERTY keyboard is in fact an example of this phenomenon. See, e.g., S.J. Liebowitz \& Stephen E. Margolis, The Fable of the Keys, 33 J.L. \& ECON. 1 (1990). For my purposes it is unimportant whether the QWERTY keyboard persists due to path dependence, so long as it is recognized that path dependence can be a real phenomenon.

104. See 1 AleXIS DE Tocoueville, Democracy in AMERICA 50 (Henry Reeve trans., 2000) (1835) ("The surface of American society is, if I may use the expression, covered with a layer of democracy, from beneath which the old aristocratic colors sometimes peep.").

105. That, at any rate, was a fear expressed by Justice Powell. See Frontiero v. Richardson, 411 U.S. 677, 692 (1973) (Powell, J., concurring) (stating that the Court should avoid deciding whether sex is a suspect classification while the ERA is pending in state legislatures). 
consider France a more deeply sexist society than our own. ${ }^{106}$ Upon reflection, however, it should not come as a surprise that different societies end up with different packages of social and legal tools to combat sex discrimination or other ills.

It also should not be surprising that different legal tools may be more or less effective for combating different forms of discrimination within a single legal system. For example, Dean Sullivan believes that greater numbers of women in positions of power would have a profound impact on the output of our public institutions, ${ }^{107}$ and she may well be right. Yet this prescription is hardly universal. Consider our other two rights movements. So long as the principal mechanism of straight supremacy is the closet, increasing numbers of (closeted) gays and lesbians in positions of public power will not likely result in substantial legal reform. In some cases, it may even impede legal reform, as those in the closet attempt to "pass" as straight by opposing equal rights based on sexual orientation. ${ }^{108}$ Nor is representation im the seats of power a practical approach to achieving legal protection for nonhuman animals-much as individual decisions might lead any of us to joke that replacing Congress, the President, or the Supreme Court with baboons would only improve the quality of their work.

There is a lesson here for egalitarian legal reformers of all stripes: Do not place all of your eggs im one basket. Political representation is undoubtedly an important element in (almost) any equality movement, but it will rarely be sufficient; legal prohibitions on concrete forms of discrimination will typically be necessary as well. ${ }^{109}$ So too, reformers should not rely on any single institution, whether it is a state legislature, Congress, an administrative agency, or the judiciary. A successful equality movement will likely need to seek change in all legal, as well as social, institutions.

106. For example, notwithstanding a formal legal prohibition, French national mores tolerate a great deal of what Americans would deem actionable sexual harassment. See Dan M. Kahan, Gentle Nudges vs. Hard Shoves: Solving the Sticky Norms Problem, 67 U. CHI. L. REv. 607, 637 (2000) (citing Abigail Cope Saguy, Defining Sexual Harassment in France and the United States, 1975-1998, at 62, 102-03 (Jan. 2000) (unpublished manuscript, on file with author)).

Viewed from a different perspective, Anglo-American constitutional traditions are generally more receptive to claims of group rights than are French universalist traditions, which is another reason why the French parity law seems especially out of place. See generally Noëlle Lenoir, The Representation of Women in Politics: From Quotas to Parity in Elections, 50 INT'L \& CoMP. L.Q. 217, 235-47 (2001) (contrasting the Anglo-American and French traditions, but nonetheless defending parity as reconcilable with the latter).

107. Sullivan, supra note 1, at 764 .

108. See generally Kenji Yoshino, Suspect Symbols: The Literary Argument for Heightened Scrutiny for Gays, 96 CoLum. L. Rev. 1753, 1793-1817, 1803 (1996) ('“Clloseted Members of Congress, especially those charged with being homosexual, may be precisely the people who need to prove they are not homosexual by distancing themselves from gay interests and even supporting antigay legislation.").

109. See John Hart Ely, Democracy and Distrust 135 (1980) (explaining why the political process alone cannot be trusted to guarantee equal rights). 


\section{CONCLUSION}

In the broad dynamic I have identified, group subordination that is initially accepted as natural comes to be challenged; the challenge is initially dismissed, but over time a social and political movement seeking reform becomes part of the mainstream. Eventually legal protection is secured, and thereafter the relation between social attitudes and legal protection is highly complex. Does the process ever come to an end? Does the legal campaign to combat discrimination against some group or on the basis of some characteristic ever succeed so well as to render legal protection unnecessary?

It is probably too early to tell. Certainly, attitudes can change. For example, anti-Irish prejudice in the United States today is nothing like what it was a century ago. ${ }^{110}$ And there are soine forms of discrimination that have all but disappeared. Left-handedness was once considered a mark of the devil, ${ }^{111}$ but today deliberate prejudice on the basis of handedness is highly unusual. ${ }^{112}$ So too, freemasons were once persecuted, ${ }^{113}$ but this prejudice is rarely salient today (although if it were, it might be prohibited in some contexts as religious discrimination). Still, other groups are still very much on the outside. Ethnic prejudice itself has not disappeared.

In any event, antidiscrimination law as such had little to do with the erosion of prejudice against the Irish, the left-handed, or freemasons. It may be that antidiscrimination law is too recent a phenomenon to have succeeded in eradicating any prejudice, even if some types of prejudices targeted by antidiscrimination law have diminished in recent years.

To understand better the work we ask of our principle of legal equality, consider the following thought experiment. Suppose that discrimination on the basis of race has been virtually eliminated. The rare person or institution that discriminates on the basis of race displays an idiosyncratic and arbitrary taste, like discriminating on the basis of month of birth. If the law sets out specific categories of proscribed discrimmation, should race be taken off the list?

The answer depends on why we think the law should delineate specific forbidden grounds of discrimination in the first place. As Dean Sullivan notes, delineation may express "the principle not only that all irrational discrimination is bad but also that discrimination by race, sex,

110. See generally NoEl IGNATIEv, How the IRISH BECAME White 2 (1996).

111. See, e.g., Roberta M. Harding, Capital Punishment As Human Sacrifice: A Societal Ritual as Depicted in George Eliot's Adam Bede, 48 BuFf. L. REv. 175, 270 n.127 (2000) (citing several sources).

112. Nevertheless, perhaps the left-handed are still victims of widespread, unintentional discrimination. See John J. Sciortino, Sinistral Legal Studies, 44 SYRacuse L. REv. 1103, 1122-24 (1993).

113. See 1 ENCYCLOPEDIA BRITANNICA 448 (15th ed. 1990) (describing the antimasonic movement in the United States). 
religion, and similar characteristics may be conclusively or nearly conclusively presumed irrational." 114 The near-eradication of some form of discrimination would not undermine such a judgment. That form of discrimination would remain irrational, even if rare.

Suppose, however, that our list of prohibited categories of discrimination does not reflect a judgment that the categories on the list are morally the most reprehensible, but instead reflects a judgment about the prevalence of particular forms of discrimination. As Dean Sullivan notes, delineation of proscribed categories "helps isolate and focus legal resources upon those social groups that are likely to experience irrational discrimination more commonly than would be the case through the random exercise of idiosyncratic tastes." 115 On this account, race discrimmation is not inherently worse than discrimination on the basis of ice-cream-flavor preference; but because the latter rarely occurs, it is less harmful when it does-a person denied a job because she prefers strawberry to vanilla will have little difficulty finding a comparable job among the vast majority of employers who do not care about her ice-cream-flavor preference, but a person denied a job because he is African American will find that this pervasive prejudice may well prevent him from obtaining like employment elsewhere. If this sort of judgment about the frequency of various forms of discrimination explains why our laws single out the categories they do, then the fading away of some form of discrimination might justify removing that form of discrimination from our list of prohibited categories. In our hypothetical postracist world, legalizing race discrimination would help conserve administrative resources for combating other, now more salient, forms of discrimination.

Still, I suspect that many of us would be uncomfortable dispensing with the prohibition on race discrimination, even in a hypothetical future society in which race discrimination is a distant memory. And that is because delineation (what Dean Sullivan calls specificity) serves as more than a cost-saving device for identifying irrational or common discrimination. Some grounds of discrimination are presumptively illegal because we as a society consider them very wrong, even if they are rational and unusual.

The shopkeeper who caters to the racism of his clients (even if he is not a racist himself), the fire department that uses gender as a proxy for strength, and the employer who does not provide wheelchair-accessible restrooms all engage in arguably rational discrimination-on the basis of race, sex, and disability, respectively. The law imtervenes nonetheless because of various value judgments. The shopkeeper should not be permitted

114. Sullivan, supra note 1 , at 749.

115. Id. 
to act as a conduit for the racism of his clients; ${ }^{116}$ women who are capable of meeting the strength standard should be judged as individuals rather than on the basis of stereotypes, even if those stereotypes are statistically accurate; and physical disabilities should be accommodated where practical.

Why are we likely to have these rather than soine other set of inoral judgments? No doubt in part because our history teaches that hierarchies based on race, sex, and disability are inore oppressive than hierarchies based on, say, handedness, birth month, or ice-cream-flavor preference. And it is certainly possible that at some point in the future, if discrinination on the basis of the latter categories becoines more salient than discrimmation on the basis of the former, our descendants will reach quite different value judgments. In other words, it may turn out that our judgments about what forms of discrinnination are wrongful (whether or not they are also irrational) closely correlate with the forms of discrimination we see inost frequently, or at least correlate with the forms of discrimmation we remember as most salient in our collective narratives.

Unfortunately, the question of what to do once the law succeeds in securing equality is a "problem" for our great-great-grandchildren. For us, the more urgent question is how the law can be used to advance equality. The modest answer I would urge is to stay situated in American experience, for our history is both a cautionary tale and a source of inspiration. The cautionary aspect reveals that even egalitarians can be blind to the mequality they perpetrate. Even as they declared that "all men are created equal," the founders of the American republic accepted the enslaveinent of millions, and many of those who sought to disentrench racial subordination in the first and second Reconstructions were blind to gender subordination. These blind spots in our past should put us on guard against too easily dismissing the claims of newer inovements.

At the same time, however, our past should inspire hope among egalitarians who seek to inake good on our constitutional commitinent to equality. As a matter of strict logic, equality without a normative conception of what inakes persons similarly situated is an empty term; ${ }^{117}$ yct, without indulging in the fallacy of inevitablism ${ }^{118}$ or American exceptionalism, we

116. Cf. Palmore v. Sidoti, 466 U.S. 429, 433-34 (1984) (holding that a state inay not give effect to private biases by using the social stigma of interracial marriage as a basis for resolving custody disputes between parents).

117. See Peter Westen, The Empty Idea of Equality, 95 HARv. L. Rev. 537, 542-48 (1982).

118. Accordingly, I think Professor Strauss overstates the case when he says that constitutional amendments have been largely irrelevant to the change in constitutional understandings since the Founding. See David A. Strauss, The Irrelevance of Constitutional Amendments, 114 HARv. L. REv. 1457,1457 (2001). The existence and wording of constitutional amendments are among the many factors that interact to create the legal regime we have at any given time, and that legal regime in turn shapes and is shaped by the larger culture. Recognizing the predominance of the social and political over the legal should not lead us to think that the legal is irrelevant. 
can see much of the history of the American republic as the gradual unfolding of a substantive conception of equality. That there remain divisive cases and difficult strategic choices is unavoidable; but despite divisions and difficulties, our shared commitment to equality is a commitment to much more than a word. It is a commitment to the possibility of a more perfect Union. 